\title{
Induction of apoptosis by phytochemicals of Ajwa dates extract in human triple-negative breast cancer cells by triggering cell cycle arrest, inhibiting Akt/mTOR signaling and modulating downstream Bcl-2 family of proteins
}

Mohsin Ali Khan

Era's Lucknow Medical College and Hospital

Sahabjada Siddiqui ( $\nabla$ sahabjada@erauniversity.in )

Era's Lucknow Medical College and Hospital https://orcid.org/0000-0003-0982-1465

Imran Ahmad

Industrial Toxicology Research Centre

Tarun Kumar Barbhuyan

Era's Lucknow Medical College and Hospital

Anand Narain Srivastava

Era's Lucknow Medical College and Hospital

Rumana Ahmad

Era's Lucknow Medical College and Hospital

\section{Research}

Keywords: Ajwa date, MDA-MB-231, Breast Cancer, Apoptosis, Cell cycle, Akt/mTOR pathway

Posted Date: March 28th, 2020

DOI: https://doi.org/10.21203/rs.3.rs-19559/v1

License: (c) (i) This work is licensed under a Creative Commons Attribution 4.0 International License.

Read Full License 


\section{Abstract}

\section{Background:}

Ajwa date (Phoenix dactylifera L.) has been described in traditional and alternative medicine to provide several health benefits including anticholesteremic, antioxidant, hepatoprotective and anticancer effects, but most remain to be scientifically validated. In the present study, we evaluated the anticancer effects of the ethanolic extract of Ajwa Dates pulp on human triple-negative breast cancer MDA-MB-231 cells.

\section{Methods}

Ajwa Dates Pulp Extract (ADPE) was phytochemically characterized using high performance liquid chromatography coupled with mass spectrometry (LC-MS). The in vitro cytotoxicity of ADPE at various concentrations viz. 10, 12, 15, 18, 20, 22 and $25 \mathrm{mg} / \mathrm{mL}$ were evaluated against MDA-MB-231 and MCF-7 cells at 24 and $48 \mathrm{~h}$. The apoptosis effect was examined by Hoechst 33342 and AO/PI-double-stain using fluorescence microscopy. The proportion of apoptotic cells, reactive oxygen species (ROS) level, mitochondrial membrane potential (MMP) and cell cycle phase distribution were estimated using flow cytometry. Apoptosis-related protein expression was determined using western blot analysis.

\section{Results}

LC-MS analysis showed that ADPE contained phytocomponents belonging to chemical classes such as carbohydrates, phenolics, flavonoids and terpenoids. Phase contrast microscopy analysis revealed various morphological variations in ADPE treated cells. MTT assay demonstrated statistically significant dose- and time-dependent inhibitions of MDA-MB-231 cells with a half-maximal inhibitory concentration of 17.45 and $16.67 \mathrm{mg} / \mathrm{mL}$ at 24 and $48 \mathrm{~h}$, respectively. Hoechst 33342 dye and DNA fragmentation data showed apoptotic cell death while AO/PI and Annexin V-FITC data revealed cells in late apoptosis at higher doses of ADPE. More importantly, Ajwa date extract prompted ROS induced alterations in MMP in ADPE treated MDA-MB-231 cells. Cell cycle analysis demonstrated that ADPE induced cell arrest in $S$ and G2/M checkpoints. In addition, ADPE upregulates p53, Bax and cleaved caspase-3, thereby leading to downregulation of bcl-2 protein and Akt/mTOR pathway.

\section{Conclusions}

The results of the present study indicate that ADPE exerts significant anticancer effects on MDA-MB-231 cells via the induction of apoptosis and suppression of AKT/mTOR signaling pathway. Therefore, ADPE has the potential to be used as an adjunct to the main line of treatment against breast cancer and can be further studied as a potential lead in breast cancer treatment.

\section{Background}

Breast cancer is an abnormal growth of cells lining the breast lobules or ducts. These cells grow uncontrollably and have the potential to spread to other parts of the body. Breast cancer impact 
2.1 million women each year, and also causes the greatest number of cancer-related deaths among women. Though, the prevalence of breast cancer in Asia is lesser than that in Western countries, but in the modern time, the relative contribution to the global burden of breast cancer is rising rapidly in Asia [1]. In 2019, there was an estimation of 268,600 new cases of invasive breast cancer among female to be reported in the US and 41,760 estimated death due to breast cancer [2]. Breast cancer is the most common cancer of females in India, which accounts for $25-32 \%$ of female cancers in India. One woman is diagnosed with breast cancer every four min and one women dies of breast cancer every thirteen min in India [3]. Breast cancer projection is expected to go as high as 17,97,900 in 2020 [4].

At the present time, various treatments including surgical resection, chemotherapy, radiation therapy, hormonal therapy and synthetic lethality have been developed. However, surgical resection at the metastasis stage often limits its effectiveness and chemotherapy and radiotherapy can have a negative effect on normal cells [5]. Therefore, treatment with insignificant adverse effects, specifically killing cancer cells with less toxicity to normal cells may present as a practical approach for improving breast cancer therapy. Molecularly targeted therapies that block tumor cell proliferation and are less toxic to normal cells, may contribute to improving survival and quality of life in breast cancer patients $[6,7]$.

Phytonutrients like carotenoids, isothiocynates, phenolic compounds, flavanoids, organo-sulphides, isoflavones and indoles found in plant-based foods such as fruits, vegetables, beans and grains may help to prevent and fight breast cancer. Foods that are rich in fiber, such as whole grains, beans, and legumes may also help in fighting breast cancer. Ajwa date fruits being a rich source of antioxidants, flavanoids as well as fiber can serve as a good anticancer agent against breast cancer. Ajwa dates (Phoenix dactylifera L.), belonging to family Arecaceae contain polyphenolics and other bioactive compounds, which are used in traditional remedies for potential prevention of cell damage and cancer therapeutics [8]. Date fruits have been consumed in Arab and its neighboring areas since time unmemorable as part of the essential diet. Recent research has shown the anticancer potential of Ajwa dates extract in combination with 5-fluorouracil against human breast adenocarcinoma cell line MCF-7 [9] and apoptosis-inducing effect and cell cycle arrest in prostate cancer cells PC3 [10]. In addition, the ethnopharmacological significance of date palm is well- described in terms of its antioxidant, antiinflammatory and antitumoral activities against breast carcinoma cells [11]. Other parts of the date palm have alos been found to exhibit potent anticancer activity viz. seed extract against azoxymethaneinduced colon carcinoma in rats, root hair extract in combination with silver nanoparticles [12] and palm pollen extract in combination with silver and gold nanoparticles against breast adenocarcinoma cells [13] and leaf extract against human malignant melanoma cell line IGR-39 [14]. However, none of the studies have, so for, reported the mechanism of anticancer action of Ajwa dates pulp extract by modulation of $\mathrm{Bcl}-2$ family proteins and downregulation of Akt/mTOR signaling pathway in breast carcinoma MDA-MB231 cells.

In the present study, MDA-MB-231 cell line was treated with various concentrations of ADPE and was analyzed for the underlying regulatory mechanism(s) of apoptotic cell death. To identify major phytoconstituents in ADPE, phytochemical characterization of ADPE was done using LC-MS. 


\section{Materials And Methods Reagents and chemicals}

Dulbecco's Modified Eagle Medium Nutrient Mixture F-12 (DMEM/F-12) and antibiotic-antimycotic (penicillin $\mathrm{G}$ and streptomycin) solution were purchased from Gibco, Invitrogen, USA. Fetal bovine serum (FBS) was procured from Himedia, India. Hoechst 33342, propidium iodide (PI), Ribonuclease A (RNase A), 2,7-dichlorodihydrofluorescein diacetate (DCFH-DA), acridine orange (AO), ethidium bromide (EtBr) and rhodamine 123 (Rh 123) were purchased from Himedia, India. Annexin V-fluorescein isothiocyanate (FITC)/propidium iodide (PI) apoptosis detection kit was supplied by BioVision, USA. The antibodies used in western blotting against $\beta$-actin, p53, Bax, Bcl-2, cleaved caspase-3, Akt, p-Akt ${ }^{473}, \mathrm{mTOR}, \mathrm{p}-\mathrm{mTOR}{ }^{2448}$ were purchased from Cell Signaling Technology (Danvers, MA). Other chemicals were obtained from Sigma-Aldrich, USA and were of analytical grade.

\section{Preparation of Ajwa dates extract}

Fresh Ajwa dates were procured from Al-Madina Al-Munawwarah, Kingdom of Saudi Arabia. The pulp part of date fruit was manually separated, washed with double distilled water, sun-dried and coarsely powdered using pestle and mortar. The coarse powder contents were then extracted in $95 \%$ ethanol (1:3 ratio, weight to volume) at $25^{\circ} \mathrm{C}$ for 3 days. The extracted solvents were pooled and filtered through Whatman No. 1 filter paper $(125 \mathrm{~mm})$. The filtrate obtained was concentrated in vacuum at $45^{\circ} \mathrm{C}$ using Rotavapor (Buchi Rotavapor R-205, Switzerland). The obtained extract was further concentrated in a water bath until a semi-solid paste was obtained and stored in an air-tight container until further use in experiments.

\section{Cell lines and cell culture}

Human estrogen negative MDA-MB-231 and estrogen positive MCF-7 breast cancer cell lines were procured from the cell repository center of the National Centre for Cell Sciences, Pune, India. These cells were cultured in DMEM/F-12 (1:1) supplemented with 10\% heat-inactivated FBS, 2 mM L-glutamine, 1\% penicillin $\mathrm{G}$ and streptomycin solution and were kept in an incubator (Thermo Scientific, USA) at $37^{\circ} \mathrm{C}$ and $5 \% \mathrm{CO}_{2}$.

\section{Photochemical Characterization of ADPE by LC-MS}

ADPE was subjected to phytochemical analysis by high-performance liquid chromatography (HPLC) coupled with mass spectrometry (MS) on triple quadrupole tandem mass spectrometer (ACQTQD\#QBB1152). LC was performed on a C18 reverse phase column $(150 \times 2.1,2.6 \mu \mathrm{m})$ and elution was done for $30 \mathrm{~min}$, using mobile phase solutions acetonitrile/water $(5: 95, \mathrm{v} / \mathrm{v})$, acetonitrile, methanol and $5 \mathrm{mM}$ ammonium acetate (95:5 $\mathrm{H}_{2} \mathrm{O}$ :Acetonitrile, $\mathrm{pH}$ 6.5). The mobile phase was kept at a flow ramp rate of $0.45 \mathrm{ml} \mathrm{min}^{-1}$ and the sample injection volume was $5 \mu$. Waters Acquity PDA detector type- UPLC eLambda $800 \mathrm{~nm}$ was used at range $210-800 \mathrm{~nm}$ and resolution $1.2 \mathrm{~nm}$. The spectrometer was operated in positive and negative modes. The source temperature was $120^{\circ} \mathrm{C}$, the desolvation temperature was 
$350^{\circ} \mathrm{C}$ and the cone voltage was set at $30 \mathrm{~V}$. MS data was recorded in the mass range, $\mathrm{m} / \mathrm{z} 200-2000$ from 0-30 min under ionization mode of $\mathrm{ES}^{+}$and $\mathrm{ES}^{-}$. All eluted peaks from HPLC were recorded at different retention times. The fractions were then characterized by mass spectrometry. This analysis was carried out at Sophisticated Analytical Instrumentation Facility (SAIF), CSIR- Central Drug Research Institute (CDRI), Lucknow, India.

\section{MTT assay}

The cell viability of ADPE against breast cancer cells was evaluated by MTT reduction assay following a previously published protocol [15]. MDA-MB-231 and MCF-7 cells were seeded at a density of $1 \times 10^{4}$ cells $/ \mathrm{mL}$ in 96 -well microtiter culture plate and incubated overnight. ADPE was diluted in culture media and treated in triplicate with varying concentrations $(10,12,15,18,20,22$ and $25 \mathrm{mg} / \mathrm{mL})$ of ADPE for 24 and $48 \mathrm{~h}$. The absorbance values were read in an ELISA plate reader (Biorad-PW41, USA) at $550 \mathrm{~nm}$ with a reference wavelength of $630 \mathrm{~nm}$. The cellular morphological changes were observed under an inverted phase-contrast microscope (Nikon Eclipse TS100, Japan).

\section{Nuclear condensation assay}

Based on the cell viability assay, the apoptosis-inducing effect of ADPE was evaluated at two effective doses viz. 15, 18 and $20 \mathrm{mg} / \mathrm{mL}$ on MDA-MB-231 cells. DNA condensation was measured using Hoechst 33258 staining as per a previously published method [16]. To assess nuclear morphology, stained cells were captured under an inverted fluorescence phase-contrast microscope (Zeiss AxioVert 135, USA).

\section{Acridine orange-ethidium bromide (AO/EtBr) assay}

The mechanism of cytotoxicity of ADPE on MDA-MB-231 cells was evaluated as reported previously. MDA-MB-231 cells were seeded in a 24-well culture plate and treated at 15 and $25 \mathrm{mg} / \mathrm{mL}$ of ADPE for $48 \mathrm{~h}$. The cells were stained with $\mathrm{AO} / \mathrm{EtBr}\left(2 \mathrm{\mu g} / \mathrm{mL}\right.$ each) fluorescent dyes for $10 \mathrm{~min}$ at $37^{\circ} \mathrm{C}$ in a $\mathrm{CO}_{2}$ incubator. Subsequently, cells were washed twice with ice-cold phosphate buffer saline (PBS) and observed under an inverted fluorescence phase-contrast microscope (Zeiss AxioVert 135, US).

\section{DNA fragmentation assay}

Genomic DNA was isolated from both treated and untreated cells as per the instruction manual of NucleoSpin ${ }^{\circledR}$ Blood Kit (Macherey-Nagel, Germany). Briefly, MDA-MB-231 cells at a density $1 \times 10^{6}$ were cultured in $\mathrm{T}-25 \mathrm{~cm}^{2}$ culture flasks overnight and cells were then treated with different concentrations of ADPE for $48 \mathrm{~h}$. Treated cells were washed with PBS and resuspended in $200 \mu \mathrm{l} \mathrm{PBS.} \mathrm{Genomic} \mathrm{DNA} \mathrm{was}$ isolated from cultured cells as per the protocol of the NucleoSpin ${ }^{\circledR}$ Blood Kit. Electrophoresis of extracted DNA was performed on $1.5 \%$ agarose gel at $60 \mathrm{~V}$ for 120 min using $1 \mathrm{X}$ TBE buffer in a gel electrophoresis unit (Genei, India). DNA bands were observed under ultraviolet illumination gel-doc system (Biorad, USA).

\section{Analysis of apoptosis by Annexin V-FITC double stain}

Apoptotic cells were quantified with an Annexin V-FITC Apoptosis Kit (BioVision, USA) according to the manufacturer's protocol using flow cytometry. Briefly, cells at $1 \times 10^{6}$ cells $/ \mathrm{mL}$ density were incubated 
with 15,18 and $20 \mathrm{mg} / \mathrm{mL}$ concentrations of ADPE for $48 \mathrm{~h}$. Cells were then harvested and re-suspended in the binding buffer and stained with $2 \mu \mathrm{l}$ Annexin V-FITC and $2 \mu \mathrm{IPI}$ for $15 \mathrm{~min}$ at $25^{\circ} \mathrm{C}$ in the dark. The apoptotic index was immediately analyzed by flow cytometry (FACS Canto II flow cytometer, BD Biosciences, USA).

\section{Intracellular ROS measurement}

Intracellular ROS levels were estimated using DCFH-DA dye by fluorescence microscopy imaging and flow cytometry techniques as reported previously [15]. The intracellular fluorescence intensity of cells was visualized by using an inverted fluorescence microscope. To quantify ROS intensity, both treated and untreated cells were harvested and washed with PBS and incubated in PBS containing $10 \mu \mathrm{M}$ DCFH-DA dye at $37^{\circ} \mathrm{C}$ for $20 \mathrm{~min}$. The cells were then washed twice with PBS and subjected to flow cytometry analysis.

\section{Mitochondrial membrane potential (MMP, $\left.\Delta \Psi_{m}\right)$ measurement}

The alterations in MMP were assessed with the fluorescent probe Rh123 as per previously published protocol [17]. The images of incubated cells were captured under a fluorescence microscope. For flow cytometry analysis, treated cells were incubated with Rh123 at a final concentration of $10 \mu \mathrm{M}$ for 30 min in the dark. After washing with PBS twice, cells were resuspended in $500 \mu \mathrm{l}$ PBS and analyzed using flow cytometry.

\section{Analysis of cellular DNA content}

Cells were seeded at density $1 \times 10^{6}$ cells $/ \mathrm{mL}$ into 6-well plate and treated with $\operatorname{ADPE}(15,18$ and $20 \mathrm{mg} / \mathrm{mL}$ ) for $48 \mathrm{~h}$. Different phases of the cell cycle with cellular DNA contents were analyzed using flow cytometry as described previously [15].

\section{Western blot analysis}

To know the expression pattern of apoptosis-inducing proteins, MDA-MB-231 cells at a density of $1 \times 10^{6}$ in T-25 $\mathrm{cm}^{2}$ flask were treated with 15,18 and $20 \mathrm{mg} / \mathrm{mL}$ concentrations of ADPE for $48 \mathrm{~h}$. At the end of each treatment, pellets were washed once in cold PBS and lysed in RIPA buffer. The lysates from each sample were centrifuged at $13000 \times \mathrm{g}$ for $10 \mathrm{~min}$ and the protein concentration in the supernatant was determined with a BCA protein assay kit (Thermo Fisher Scientific Inc. USA) as per manual instruction. Equal amounts $(40 \mu \mathrm{g})$ from each sample of protein lysate were subjected to SDS-PAGE on $6 \%$ gel for mTOR/p-MTOR, 12\% gel for Akt/p-Akt, p53, bax, bcl-2, cleaved caspase-3. Mini Trans-Blot@ Module (Biorad) was used to electrotransfer separated proteins to a PVDF membrane and thereafter the blot was blocked with blocking buffer containing 5\% BSA in Tris Buffer Saline Tween 20 (TBST) solution, pH 7.4 under constant agitation for $1 \mathrm{~h}$ at $4{ }^{\circ} \mathrm{C}$. Membranes were then incubated with primary antibodies overnight at $4{ }^{\circ} \mathrm{C}$. Following washing with TBST thrice, membranes were incubated with horseradish peroxidase (HRP)- conjugated secondary antibodies for $1 \mathrm{~h}$ at RT with gentle shaking. After washing, 
bands were visualized by ECL Western Blotting Substrate Kit (Thermo Fischer Scientific, USA) according to the manufacturer's instructions. The relative abundance of each band was quantified using Image $\mathrm{J}$ software (version 1.43, NIH, USA) for Windows. Blots were reported with the $\beta$-actin antibody as a loading control.

\section{Statistical analysis}

Cell viability data were expressed as the mean \pm SEM from three independent experiments. Statistical evaluation was determined by one-way ANOVA followed by Dunnett's Multiple Comparison Test using GraphPad Prism software (Version 5.01). A P-value of less than 0.05 was considered statistically significant.

\section{Results}

\section{Identification of phytocomponents}

Most probable adducts were recognized to be $[\mathrm{M}+\mathrm{H}]^{+},[\mathrm{M}+\mathrm{Na}]^{+},[\mathrm{M}+\mathrm{K}]^{+}$and $[\mathrm{M}+\mathrm{K}+2 \mathrm{H}]^{+}$which were used for analysis of MS data qualitatively. The names, $M W s$, and retention time $\left(R_{t}\right)$ of compounds contained in ADPE were ascertained. LC-MS chromatogram of ADPE showed eight peaks indicative of presence of eight bioactive components (Fig. 1). On comparison of the mass spectra of the constituents, eight phytocomponents were characterized and identified as shown in Table 1. The compounds having the highest peak were identified as maltose, catechin, myricetin, quercetin, $\beta$-sitosterol, digalacturonic acid, chlorogenic acid and $\beta$-carotene.

\section{Morphological variations and cell viability of MDA-MB-231 cells}

MDA-MB-231 and MCF-7 cells were treated with increasing concentrations of ADPE and photographed at 24 and $48 \mathrm{~h}$ of ADPE exposure. ADPE exhibited more cytotoxic to MDA-MB-231 in comparison to MCF-7 cells. Therefore, based on the excessive activity on TNBC, this cell line was further processed for anticancer study. Morphological comparison of treated and untreated MDA-MB-231 cells revealed significant ADPE-mediated variations. As shown in Fig. $2 \mathrm{~A}$, the control/non-treated cells exhibited normal features such as a typical adherent and homogeneous cell surface at both 24 and $48 \mathrm{~h}$ of incubation. Following exposure to $10-25 \mathrm{mg} / \mathrm{mL}$ ADPE for $24 \mathrm{~h}$, majority of MDA-MB-231 cells developed a nonadherent, detached, and rounded morphology. Moreover, ADPE increased the typical morphological apoptotic variations in MDA-MB-231 cells at $48 \mathrm{~h}$ incubation; showing both dose-and time-dependent activities. As indicated in Fig. 2C, ADPE reduced cell viability to 94.8, 87.3, 68.2, 52, 39.1, 31.4 and 21.8\% at $10,12,15,18,20,22$ and $25 \mathrm{mg} / \mathrm{mL}$, respectively at $24 \mathrm{~h}$ incubation period. ADPE exerted a more pronounced cytotoxic effect at $48 \mathrm{~h}$, reducing the viability of treated MDA-MB-231 cells to $92.1,82.7,60.7$, $44.1,34.3,23.8$ and $16.3 \%$, respectively at the respective doses of ADPE. Thus, the cell viability data suggested that ADPE treatment significantly reduced MDA-MB-231 cell growth in both dose- and time- 
dependent manner. The $\mathrm{IC}_{50}$ value of $\mathrm{ADPE}$ was found to be 17.45 and $16.67 \mathrm{mg} / \mathrm{mL}$ after 24 and $48 \mathrm{~h}$ exposure, respectively (Fig. 2D).

\section{ADPE stimulates chromatin condensation and induces apoptosis}

As is evident from the photomicrograph (Fig. 3A), ADPE increased the chromatin condensation in MDAMB-231 cells depending upon dose. Doses 15 and $18 \mathrm{mg} / \mathrm{mL}$ showed less condensation of nucleus whereas $20 \mathrm{mg} / \mathrm{mL}$ of ADPE exhibited maximum nuclear condensation. As shown in AO/EtBr staining, control cells appeared live and healthy having uniformly green-colored nucleus, while treated cells aappeared to be either in early apoptosis (green-colored with condensed nuclei) or in late apoptosis stage (orange-red colored cells with condensed nuclei). Higher doses of ADPE increased the late apoptotic features (Fig. 3B). ADPE was further analyzed to determine DNA fragmentation in MDA-MB-231 cells. Intact undamaged DNA band was obtained in control well, while treated cells displayed progressive DNA damage and fragmentation depending upon dose (Fig. 3C). ADPE at $15 \mathrm{mg} / \mathrm{mL}$ showed less shearing of DNA, but it was found to be increased at $20 \mathrm{mg} / \mathrm{mL}$ of extract.

\section{Quantification of early and late apoptosis}

To quantify early and late apoptosis, MDA-MB-231 cells were evaluated further by Annexin V-FITC Apoptosis Detection Kit (Biovision, USA). Untreated cells showed $88.2 \%$ live and in a intact physical shape whereas ADPE at $15 \mathrm{mg} / \mathrm{mL}$ increased cell death by decreasing live cells percentage to $72.2 \%$ and enhanced percentage of early apoptotic (1.6\%) and late apoptotic (8.3\%) cells (Fig. 3D). The dose 18 and $20 \mathrm{mg} / \mathrm{mL}$ caused significant increase in percentage of late apoptotic cells to 21.9 and $22.4 \%$, respectively.

\section{Intracellular ROS generation by ADPE}

The flow cytometry analysis of ROS measurement revealed that the level of ROS in control cells was $5.5 \%$. This small amount of ROS level shows the characteristic feature of normal healthy cells. ROS levels were enhanced by 8.5 and $14.7 \%$ at 15 and $18 \mathrm{mg} / \mathrm{mL}$ of ADPE as compared to control. Moreover, ROS production in treated cells was increased enormously by $51.9 \%$ at $20 \mathrm{mg} / \mathrm{mL}$ of ADPE (Fig. 4B). The fluorescent microscopy analysis of ROS intensity was found to be consistent with flow cytometry data (Fig. 4A).

\section{ADPE decreases the MMP}

As is evidenced in photomicrograph (Fig. 4C), the red fluorescent intensity of dye Rh123 was inversely proportional to increasing doses of ADPE due to loss of MMP in treated cells. Flow cytometry analysis depicted the percent level of MMP at various doses of ADPE (Fig. 4D). The untreated MDA-MB-231 cells exhibited a MMP of $5.5 \%$ whereas it was decreased to $2.4,2$ and $1.5 \%$ at 15,18 and $20 \mathrm{mg} / \mathrm{mL}$ of $A D P E$, 
respectively. Results suggest that ADPE causes a dose-dependent decrease in MMP in treated MDA-MB231 cells.

\section{ADPE induces $S$ and $G_{2} / M$ phase arrest}

MDA-MB-231 cells were treated with ADPE for $24 \mathrm{~h}$ and then subjected to cell cycle analysis using flow cytometry. As shown in Fig. 5, ADPE substantially increased the number of MDA-MB-231 cells in the $S$ phase which was accompanied by a proportional decrease in the percentage of cells in the G0/G1 phase. ADPE also sparingly increased the proportion of cells in the $\mathrm{G} 2 / \mathrm{M}$ phase of the cell cycle. These results indicate that ADPE arrested the cell cycle of MDA-MB-231 cells in both $S$ and G2/M phase.

\section{ADPE down-regulates Akt/mTOR signaling pathway and modulates downstream Bcl-2 family proteins}

To investigate the mechanisms underlying ADPE-induced cell death, immunoblot analysis was carried out for the expression of key markers such as tumor suppressor p53, pro-apoptotic Bax, anti-apoptotic Bcl2, and effector caspase i.e. cleaved caspase-3. Further, the expression of mTOR and Akt molecules were investigated to analyze the intracellular signaling pathway. Results showed that Bax was upregulated and $\mathrm{Bcl} 2$ was down-regulated in ADPE treated cells. The expression of p53 and cleaved caspase-3 was increased in MDA-MB-231 cell line following $48 \mathrm{~h}$ of ADPE treatment. Moreover, the results demonstrated that both p-AKT and p-mTOR levels were reduced in MDA-MB-231 cells following $48 \mathrm{~h}$ of ADPE treatment (Fig. 6). These results indicate that ADPE inhibits AKT/mTOR signaling pathway important in regulating cell growth and proliferation in breast cancer cells.

\section{Discussion}

Among breast cancer, TNBC has increased the risk of cancer progression and also poorer prognosis due to the lack of targeted hormonal therapy. Herbal extracts and their isolated molecules have been found to be effective against various cancers [18]. In the present study, the unprecedented evaluation of mitochondrial-mediated apoptosis, cell cycle arrest and underlying intracellular signaling pathways of cell death were carried out using ADPE against human TNBC MDA-MB-231 cells.

The anti-proliferative effect of ADPE on MDA-MB-231 cell lines has been shown in Fig. 1. The MTT results show that exposure of MDA-MB-231 cells to ADPE resulted in growth inhibition of cells in a dose- and time-dependent manner. ADPE showed $\mathrm{IC}_{50}$ values of 17.45 and $16.67 \mathrm{mg} / \mathrm{mL}$ at 24 and $48 \mathrm{~h}$, respectively. Since majority of the phytocomponents present in the pulp of Ajwa dates were characterized as polysaccharides in LC-MS, therefore, larger proportions are needed to elicit biological efficacy of ADPE. This study suggests that consumption of large portions of Ajwa dates may be conducive to lead a healthy and cancer-free life. The morphological data under inverted phase-contrast microscopy revealed the natural and fibroblastic morphology of untreated TNBC cells. ADPE caused a decrease in the number of cells by an alteration in their shape and adherence. These events represent the classic features of early 
apoptosis [19]. Further, to confirm apoptosis cell death, MDA-MB-231 cells were investigated using Hoechst 33258 nuclear stain under a fluorescence microscope. The treated cells displayed cell shrinkage, blebbing of plasma membrane without loss of integrity, nuclear condensation and formation of pyknotic bodies (Fig. 3). Further, AO/EtBr double stain was used to analyze the early and late apoptosis in ADPE treated cells. In early apoptosis, AO binds within the fragmented DNA of the cells emanating bright green fluorescence, while in late apoptosis; PI binds to denatured DNA displaying reddish-orange color. This study suggests that lower doses of ADPE lead to early apoptosis, while higher doses lead to the late stages of apoptosis. For quantitative analysis, treated cells were stained with Annexin- V/PI double stain and examined with flow cytometry. The result depicted that the percentage of viable cells decreased with a concomitant increase in the percentage of cells undergoing early and late apoptosis. At a low dose, ADPE treatment resulted in early apoptotic cells while late apoptotic stages were found at higher doses (Fig. 4). This data suggests that ADPE treatment pushes the cancer cells into late apoptosis stage. A previous study has also reported that methanolic extract of Ajwa dates induces apoptosis in breast cancer MCF-7 cells by increasing the percentage of cells in late apoptosis [20]. DNA fragmentation data also confirmed the apoptosis-inducing efficacy of ADPE against MDA-MB-231 cells.

The regulation of intracellular ROS levels is crucial in maintaining cellular homeostasis and thus, different ROS levels can cause diverse biological responses. At low levels, ROS act as signaling molecules while at high levels they induce cell damage and death [21]. Therefore, the generation of ROS levels in treated cells was examined using DCFH-DA stain through fluorescence microscopy and flow cytometry study. Results revealed that ADPE induced the level of ROS generation in a dose-dependent manner. Excess cellular levels of ROS are responsible for damaging the various biomolecules such as proteins, lipids, nucleic acids, cell membranes and organelles which may result in progressive cell dysfunctions and cellular apoptosis [22]. Oxidative stress can disrupt the balance between ROS production and radical-scavenging leading to loss of MMP and release of cytochrome $c$ from the intracellular space of the mitochondria and resulting in cellular apoptosis [23]. Thus, ADPE has been found to decrease MMP in MDA-MB-231 cells in a dose-dependent manner. Moreover, excessive ROS production can activate various signaling molecules in cancer cells which initiate cell cycle arrest and apoptosis [24]. The cell cycle data revealed that ADPE treatment of MDA-MB-231 cells resulted in arrest of cells in S phase and sparingly in the G2/M phase with an accompanying decrease in the G0/G1 phase. This study confirmed that ADPE interferes the initiation of DNA replication and thus arrests MDA-MB-231 cells at the $S$ phase, while cells arrested in G2/M phase by ADPE restricts the cells to repair damaged DNA before entering mitosis. A previous study has also shown that Allium atroviolaceum flower extract induces $S$ and G2/M phase arrest in MCF-7 and S phase arrest in MDA-MB-231 cells [25].

ROS cause cell cycle arrest and induce apoptosis by activating various signaling cascades and signalregulating kinase pathways $[22,26]$. Apoptosis also requires permeabilization of the outer mitochondrial membrane which is controlled by the Bcl-2 family proteins. Therefore, the present study also attempted validation of our hypothesis on the modulation of the Bcl-2 family proteins and signal-regulating Akt/mTOR pathway in the ADPE-extract mediated apoptosis against MDA-MB-231 cells. For this, we analyzed protein expression of p53, Bax, Bcl-2 and cleaved caspase-3, along with the expression of p-AKT 
and p-mTOR in ADPE- treated MDA-MB-231 cells. Protein expression data has revealed that ADPE increases the expression of tumor suppressor p53, pro-apoptotic Bax, and effector cleaved caspase-3, while reduces the expression of anti-apoptotic Bcl-2 protein. Tumor suppressor p53 gene, also called guardian of the genome, plays an important role in cell growth inhibition and induction of apoptosis after DNA damage. After DNA damage, p53 gene is activated and it promotes high expression of pro-apoptotic regulator Bax and low expression of anti-apoptotic gene Bcl-2. Eventually, the modulation of the Bcl-2 family proteins initiates caspases cascade reaction and activates caspase-3 resulting in nuclear apoptosis $[22,27]$. Thus, our results clearly show that ADPE exhibited apoptosis via intrinsic pathway.

Growth factors can suppress apoptosis and regulate cell growth and cell survival in a transcription independent manner by activating the serine/threonine specific protein kinase, Akt [28]. Activated Akt, also known as Protein kinase B (PKB), translocates to the cytoplasm and nucleus and activates a number of downstream targets following activation of mTOR [29]. The mammalian target of rapamycin (mTOR) functions as a serine/threonine protein kinase, which can affect gene transcription and translation by regulating cell growth, cell proliferation and cell survival [30]. Akt promotes cell survival by inhibiting apoptosis, and thus it can be said that Akt is downregulated during apoptosis processes. Therefore, due to suppression of the AKT/mTOR pathway, cells lose their survival and proliferation capability; which may trigger programmed cell death, including apoptosis, autophagy and necroptosis. Interestingly, our protein expression data revealed that the expression level of p-AKT and p-mTOR undergoes a down regulation after $48 \mathrm{~h}$ in ADPE treated MDA-MB-231 cells. A previous study has also reported that Murraya koenigii leaves extract induced mitochondrial apoptosis in DLD-1 colon cancer cells by downregulating mTOR/AKT pathway [31]. LC-MS data revealed the presence of carbohydrates containing disaccharides and their derivative along with phenolics, flavonoids, phytosterols, and carotenoids in ADPE. The identified bioactive components such as maltose, catechin, myricetin, quercetin, $\beta$-sitosterol, digalacturonic acid, chlorogenic acid and $\beta$-carotene are known to exhibit various pharmacological activities such as antioxidant, anti-inflammatory, antimicrobial, hepatoprotective and anticancer [32, 33].

\section{Conclusions}

In conclusion, the present study has revealed the potent growth-inhibitory effect of Ajwa dates pulp against human TNBC MDA-MB-231 cells. The growth-inhibitory effect was found to be associated with ROS generation, MMP depletion, cell cycle arrest, upregulation of tumor suppressor $p 53$, pro-apoptotic Bax, and effector cleaved caspase-3 and downregulation of anti-apoptotic Bcl-2 protein, p-AKT and pmTOR signaling molecules. Figure 7 summarizes the proposed mechanism of action underlying the anticancer effect of ADPE against MDA-MB-231 cells. It is evident from the present study that ADPE has the potential for being developed into a novel and potent anticancer drug against human breast cancer in future, and/or as a powerful adjunct to the mainline of breast cancer therapy; albeit with further clinical studies to validate the therapeutic basis of drug development.

\section{Abbreviations}


ADPE: Ajwa Dates Pulp Extract; LC-MS: Liquid Chromatography coupled with Mass Spectrometry ; AO: Acridine Orange; Caspase-3: cysteine-aspartic acid protease-3; DAPI: 4', 6'-diamidino-2 phenylindole; DCFH-DA: 2,7-dichlorodihydrofluorescein diacetate; DMSO: dimethylsulfoxide; ELISA: enzyme linked immunosorbent assay; FBS: fetal bovine serum; MMP: mitochondrial membrane potential; MTT: 3-(4,5dimethylthiazol-2-yl)-2,5-diphenyltetrazolium bromide; PI: propidium iodide; ROS: reactive oxygen species; mTOR: mammalian target of rapamycin; PKB: Protein kinase B; SEM: standard error mean.

\section{Declarations}

\section{Ethics approval and consent to participate}

Not applicable.

\section{Consent for publication}

Not applicable.

\section{Availability of data and material}

All data generated or analyzed during this study are included in this manuscript.

\section{Competing interests}

The authors declare that they have no potential conflicts of interest.

\section{Funding:}

Not applicable.

\section{Authors' contributions}

MAK, SS, RA and ANS conceived and designed the study. SS and TKV conducted the experiments. MAK and IA contributed reagents/materials. SS and RA analyzed the data. SS and RA prepared the manuscript. SS, IA, TKV and RA helped with the biological analysis. SS, RA and ANS critically reviewed the manuscript and suggested modifications. All authors read and approved the final manuscript.

\section{Acknowledgements}

The authors express their gratitude to Mr. Puneet Khare, Senior Technician, Central Facility, CSIR-IITR, for providing technical assistance in flow cytometry analysis and Mr. R.K. Purshottam, Senior Technical Officer, CSIR-CDRI, Lucknow, for HPLC analysis. The authors also wish to extend their appreciation to Laboratory for Stem Cell \& Restorative Neurology Department of Biotechnology, for western blot analysis and the In-charge of Cell \& Tissue Culture Laboratory, Department of Biochemistry, Era's Lucknow Medical College \& Hospital, Era University, for providing basic infrastructure and cell culture facility. 


\section{References}

1. Fitzmaurice C, Allen C, Barber RM, Barregard L, Bhutta ZA, Brenner H, Dicker DJ, Chimed-Orchir O, Dandona R, Dandona L, Fleming T. Global, regional, and national cancer incidence, mortality, years of life lost, years lived with disability, and disability-adjusted life-years for 32 cancer groups, 1990 to 2015: a systematic analysis for the global burden of disease study. JAMA oncology. $2017 \mathrm{Apr}$ 1;3(4):524-48.

2. https://seer.cancer.gov/statfacts/html/breast.html/ (access on March 05, 2020).

3. https://www.oncostem.com/blog/alarming-facts-about-breast-cancer-in-india/ (access on March 10, 2020)

4. Malvia S, Bagadi SA, Dubey US, Saxena S. Epidemiology of breast cancer in Indian women. Asian Pacific Journal of Clinical Oncology. 2017 Aug;13(4):289-95.

5. Arruebo M, Vilaboa N, Sáez-Gutierrez B, Lambea J, Tres A, Valladares M, González-Fernández Á. Assessment of the evolution of cancer treatment therapies. Cancers. 2011 Sep;3(3):3279-330

6. Schlotter $\mathrm{CM}$, Vogt $\mathrm{U}$, Allgayer $\mathrm{H}$, Brandt B. Molecular targeted therapies for breast cancer treatment. Breast cancer research. 2008 Aug;10(4):211.

7. A Baudino T. Targeted cancer therapy: the next generation of cancer treatment. Current drug discovery technologies. 2015 Mar 1;12(1):3-20.

8. Yasin BR, El-Fawal HA, Mousa SA. Date (Phoenix dactylifera) polyphenolics and other bioactive compounds: A traditional islamic remedy's potential in prevention of cell damage, cancer therapeutics and beyond. International journal of molecular sciences. 2015 Dec;16(12):30075-90.

9. Khan F, Aldhahri M, Hussain MA, Gauthaman K, Memic A, Abuzenadah A, Kumosani T, Barbour E, Alothmany NS, Aldhaheri RW. Encapsulation of 5-flurouracil into PLGA nanofibers and enhanced anticancer effect in combination with Ajwa-dates-extract (Phoenix dactylifera L.). Journal of biomedical nanotechnology. 2018 Mar 1;14(3):553-63.

10. Mirza MB, Elkady Al, Al-Attar AM, Syed FQ, Mohammed FA, Hakeem KR. Induction of apoptosis and cell cycle arrest by ethyl acetate fraction of Phoenix dactylifera L.(Ajwa dates) in prostate cancer cells. Journal of ethnopharmacology. 2018 May 23;218:35-44.

11. El Abed H, Chakroun M, Abdelkafi-Koubaa Z, Drira N, Marrakchi N, Mejdoub H, Khemakhem B. Antioxidant, anti-inflammatory, and antitumoral effects of aqueous ethanolic extract from Phoenix dactylifera L. parthenocarpic dates. BioMed research international. 2018;2018.

12. Oves M, Aslam M, Rauf MA, Qayyum S, Qari HA, Khan MS, Alam MZ, Tabrez S, Pugazhendhi A, Ismail IM. Antimicrobial and anticancer activities of silver nanoparticles synthesized from the root hair extract of Phoenix dactylifera. Materials Science and Engineering: C. 2018 Aug 1;89:429-43.

13. Banu H, Renuka N, Faheem SM, Ismail R, Singh V, Saadatmand Z, Khan SS, Narayanan K, Raheem A, Premkumar K, Vasanthakumar G. Gold and silver nanoparticles biomimetically synthesized using date palm pollen extract-induce apoptosis and regulate $\mathrm{p} 53$ and Bcl-2 expression in human breast adenocarcinoma cells. Biological trace element research. 2018 Nov 1;186(1):122-34. 
14. Chakroun M, Khemakhem B, Mabrouk HB, El Abed H, Makni M, Bouaziz M, Drira N, Marrakchi N, Mejdoub H. Evaluation of anti-diabetic and anti-tumoral activities of bioactive compounds from Phoenix dactylifera L's leaf: In vitro and in vivo approach. Biomedicine \& Pharmacotherapy. 2016 Dec 1;84:415-22.

15. Siddiqui S, Ahamad MS, Jafri A, Afzal M, Arshad M. Piperine triggers apoptosis of human oral squamous carcinoma through cell cycle arrest and mitochondrial oxidative stress. Nutrition and cancer. 2017 Jul 4;69(5):791-9

16. Huang RP, Hossain MZ, Huang R, Gano J, Fan Y, Boynton AL. Connexin 43 (cx43) enhances chemotherapy-induced apoptosis in human glioblastoma cells. International journal of cancer. 2001 Apr 1;92(1):130-8.

17. Fan J, Wang P, Wang X, Tang W, Liu C, Wang Y, Yuan W, Kong L, Liu Q. Induction of mitochondrial dependent apoptosis in human leukemia K562 cells by meconopsis integrifolia: A species from traditional Tibetan medicine. Molecules. 2015 Jul;20(7):11981-93.

18. Demain AL, Vaishnav P. Natural products for cancer chemotherapy. Microbial biotechnology. 2011 Nov;4(6):687-99.

19. Elmore S. Apoptosis: a review of programmed cell death. Toxicologic pathology. 2007 Jun;35(4):495516.

20. Khan F, Ahmed F, Pushparaj PN, Abuzenadah A, Kumosani T, Barbour E, AlQahtani M, Gauthaman K. Ajwa date (Phoenix dactylifera L.) extract inhibits human breast adenocarcinoma (MCF7) cells in vitro by inducing apoptosis and cell cycle arrest. PloS one. 2016;11(7).

21. Khan MN, Mobin M, Abbas ZK, AlMutairi KA, Siddiqui ZH. Role of nanomaterials in plants under challenging environments. Plant Physiology and Biochemistry. 2017 Jan 1;110:194-209.

22. Redza-Dutordoir M, Averill-Bates DA. Activation of apoptosis signalling pathways by reactive oxygen species. Biochimica et Biophysica Acta (BBA)-Molecular Cell Research. 2016 Dec 1;1863(12):297792.

23. Nita M, Grzybowski A. The role of the reactive oxygen species and oxidative stress in the pathomechanism of the age-related ocular diseases and other pathologies of the anterior and posterior eye segments in adults. Oxidative Medicine and Cellular Longevity. 2016;2016.

24. Aggarwal V, Tuli HS, Varol A, Thakral F, Yerer MB, Sak K, Varol M, Jain A, Khan M, Sethi G. Role of Reactive Oxygen Species in Cancer Progression: Molecular Mechanisms and Recent Advancements. Biomolecules. 2019 Nov;9(11):735.

25. Khazaei S, Abdul Hamid R, Ramachandran V, Mohd Esa N, Pandurangan AK, Danazadeh F, Ismail P. Cytotoxicity and Proapoptotic Effects of Allium atroviolaceum Flower Extract by Modulating Cell Cycle Arrest and Caspase-Dependent and p53-Independent Pathway in Breast Cancer Cell Lines. Evidence-Based Complementary and Alternative Medicine. 2017;2017.

26. Zhao Q, Liu Y, Zhong J, Bi Y, Liu Y, Ren Z, Li X, Jia J, Yu M, Yu X. Pristimerin induces apoptosis and autophagy via activation of ROS/ASK1/JNK pathway in human breast cancer in vitro and in vivo. Cell death discovery. 2019 Aug 5;5(1):1-3. 
27. Elmore S. Apoptosis: a review of programmed cell death. Toxicologic pathology. 2007 Jun;35(4):495516.

28. Brunet A, Bonni A, Zigmond MJ, Lin MZ, Juo P, Hu LS, Anderson MJ, Arden KC, Blenis J, Greenberg ME. Akt promotes cell survival by phosphorylating and inhibiting a Forkhead transcription factor. cell. 1999 Mar 19;96(6):857-68.

29. Hahn-Windgassen A, Nogueira V, Chen CC, Skeen JE, Sonenberg N, Hay N. Akt activates the mammalian target of rapamycin by regulating cellular ATP level and AMPK activity. Journal of Biological Chemistry. 2005 Sep 16;280(37):32081-9.

30. Tee AR. The target of rapamycin and mechanisms of cell growth. International journal of molecular sciences. 2018 Mar;19(3):880.

31. Arun A, Patel OP, Saini D, Yadav PP, Konwar R. Anti-colon cancer activity of Murraya koenigii leaves is due to constituent murrayazoline and O-methylmurrayamine A induced mTOR/AKT downregulation and mitochondrial apoptosis. Biomedicine \& Pharmacotherapy. 2017 Sep 1;93:510-21.

32. Kumar S, Pandey AK. Chemistry and biological activities of flavonoids: an overview. The Scientific World Journal. 2013;2013.

33. Coman V, Teleky BE, Mitrea L, Martău GA, Szabo K, Călinoiu LF, Vodnar DC. Bioactive potential of fruit and vegetable wastes. Adv. Food Nutr. Res. 2019 Aug 1

\section{Table}

Due to technical limitations, Table 1 is provided in the Supplementary Files section.

\section{Figures}




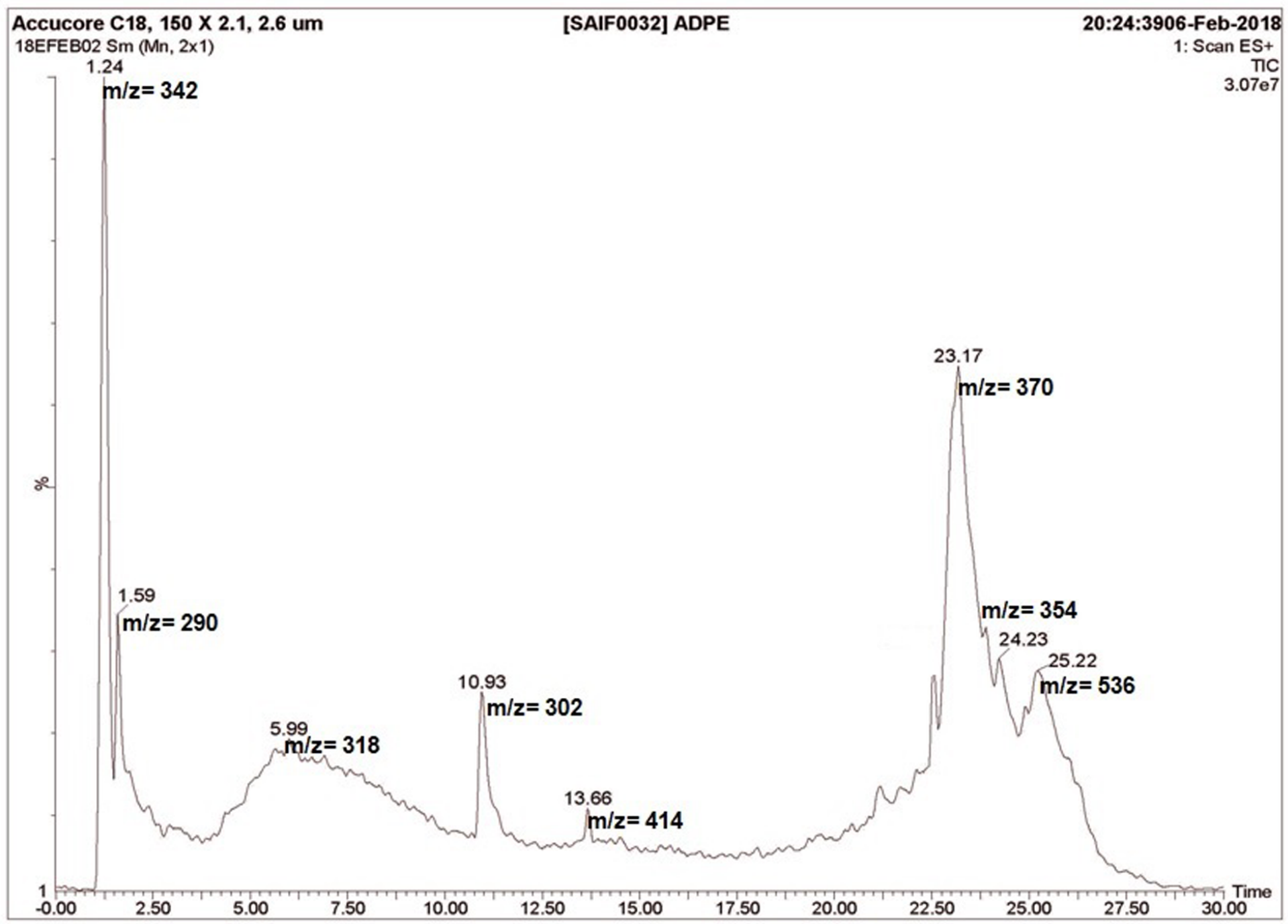

Figure 1

Total Ion Chromatogram (TIC) of 95\% ethanolic ADPE obtained using LC-MS. $5 \mathrm{~mL}$ of sample was loaded on Silica C18 Reversed Phase column $(150 \times 2.1,2.6 \mu \mathrm{m})$, with $0.45 \mathrm{ml}$ min-1 flow rate using mobile phase solvents (A): acetonitrile/water (5:95, v/v), (B): acetonitrile, (C): methanol and (D): $5 \mathrm{mM}$ ammonium acetate (95:5 H2O:Acetonitrile, $\mathrm{pH}$ 6.5). Mass spectrometry was performed by ESI and MS data was recorded in the mass range $\mathrm{m} / \mathrm{z}$ 200-2000 from 0-30 min under ionization mode of ES+ and ES-. Y-axis is relative abundance and $\mathrm{X}$-axis is retention time. 
A

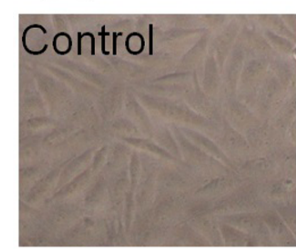

$18 \mathrm{mg} / \mathrm{mL}$

so

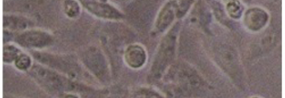

B

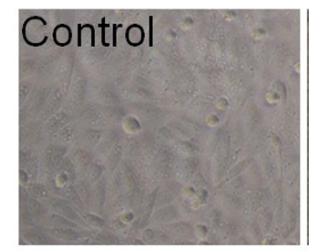

$18 \mathrm{mg} / \mathrm{mL}$

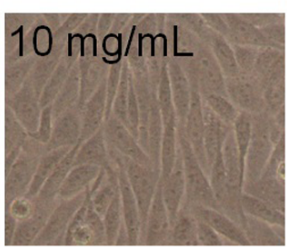

$20 \mathrm{mg} / \mathrm{mL}$
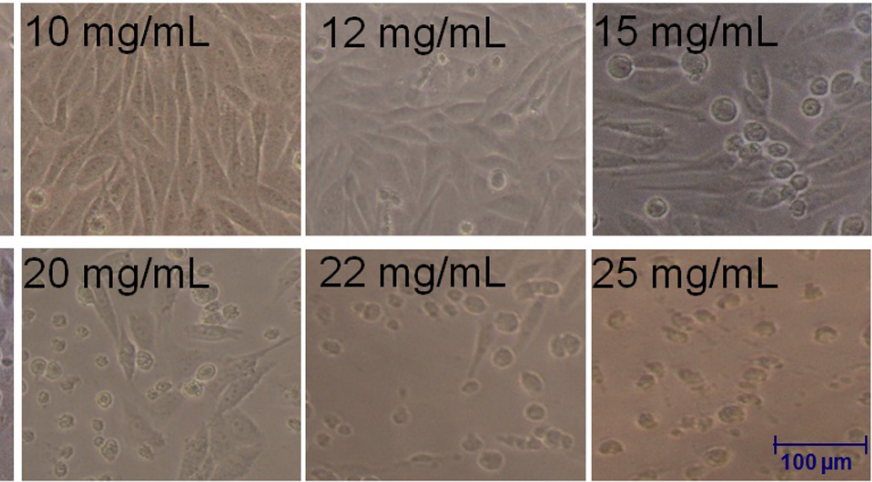

$100 \mu \mathrm{m}$

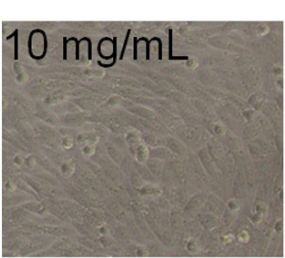

$20 \mathrm{mg} / \mathrm{mL}$

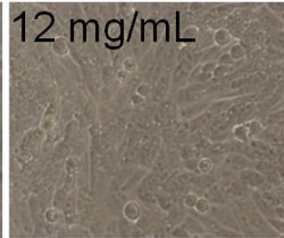

$22 \mathrm{mg} / \mathrm{mL}$

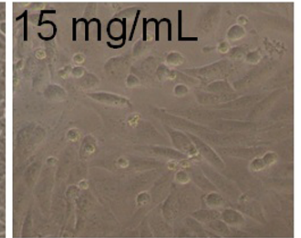

$25 \mathrm{mg} / \mathrm{mL}^{\mathrm{L}}$
C
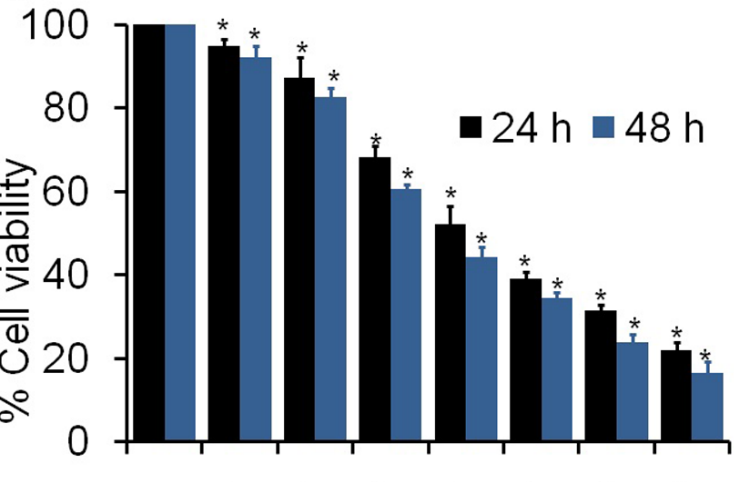

$0 r^{0} \lambda^{2} \kappa^{5} \lambda^{8} \eta^{0} \eta^{5}$ EEADP concentration $(\mathrm{mg} / \mathrm{mL})$
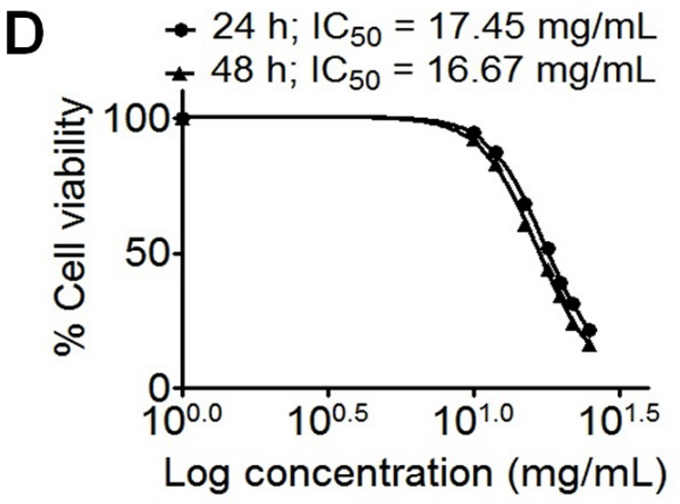

Figure 2

Microscopic observation and cytotoxic activity of different concentrations $(10-25 \mathrm{mg} / \mathrm{mL})$ of ADPE against MDA-MB-231 and normal Vero cells (A) \& (B) Photomicrograph of MDA-MB-231 cells treated with 10 to $25 \mathrm{mg} / \mathrm{mL}$ concentrations of ADPE at 24 and $48 \mathrm{~h}$, respectively. Photomicrographs were taken with an inverted phase contrast microscope. Scale bar $=100 \mu \mathrm{m}$. (C) Percent cell viability of ADPE at various concentrations on MDA-MB-231 cells after 24 and $48 \mathrm{~h}$ incubation. (D) Dose response curve (Log concentration vs \% cell viability) representing IC50 values of ADPE at 24 and $48 \mathrm{~h}$ incubation. Values are expressed as mean \pm SEM of three independent experiments. ${ }^{*} p<0.05$ as compared to control. 

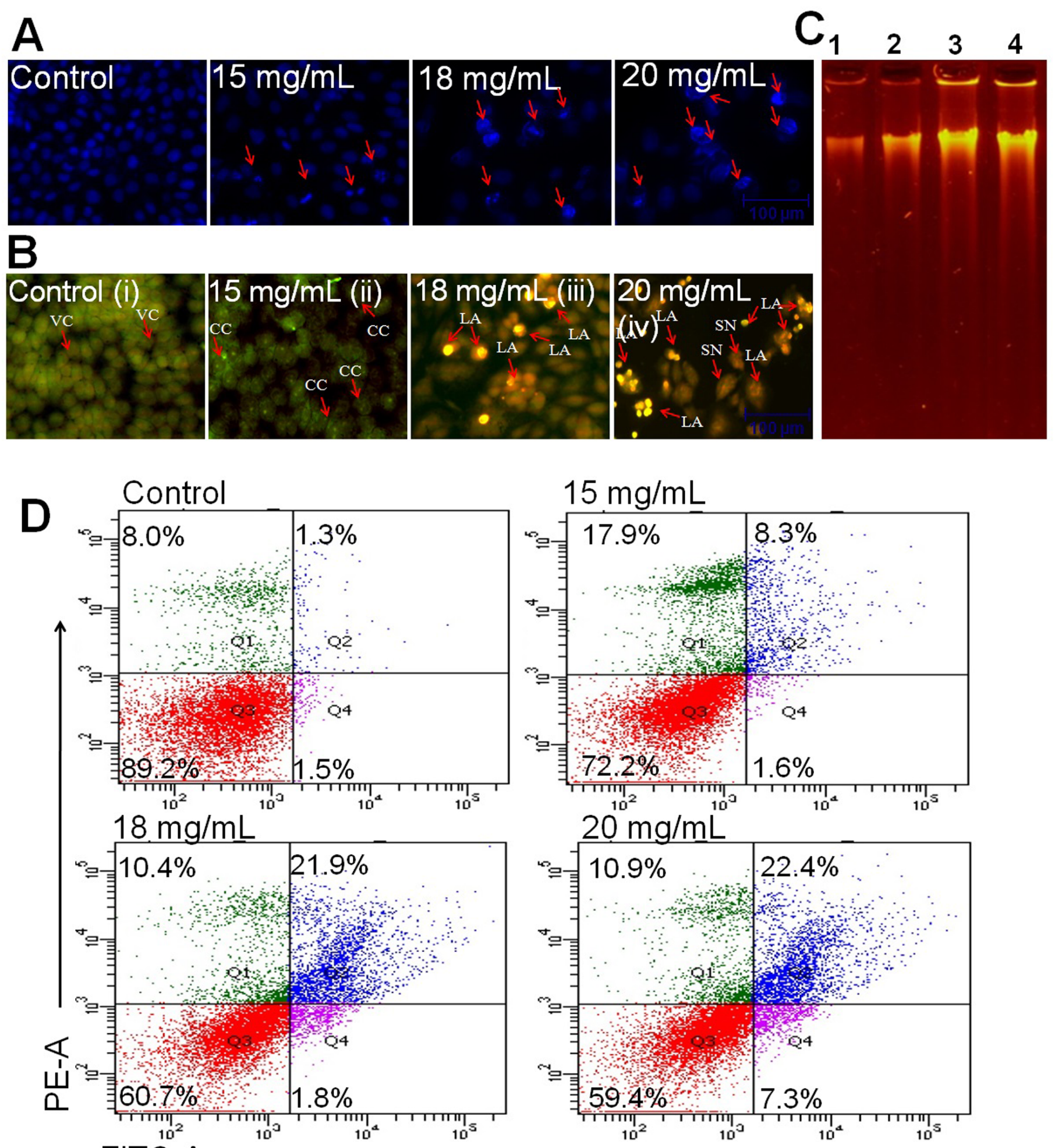

FITC-A

Figure 3

Apoptosis-inducing activity of ADPE in MDA-MB-231 treated cells (A) Chromatic condensation of MDAMB-231 treated cells at 15, 18 and $20 \mathrm{mg} / \mathrm{mL}$ of ADPE for $48 \mathrm{~h}$. (B) Fluorescent micrographs of AO/PIdouble-stained MDA-MB-231 cells at 15, 18 and $20 \mathrm{mg} / \mathrm{mL}$ of ADPE after $48 \mathrm{~h}$. (i) Untreated MDA-MB-231 cells depict healthy structure (ii) Early apoptosis features such as chromatin condensation and membrane blebbing were observed at $15 \mathrm{mg} / \mathrm{mL}$ of ADPE (iv) Late apoptosis and secondary necrosis 
were observed at $20 \mathrm{mg} / \mathrm{mL}$ of extract. Scale bar= $100 \mu \mathrm{m}$. VC: Viable cells; CC: Chromatin condensation; LA: Late apoptosis and SN: Secondary necrosis. Scale bar= $100 \mu \mathrm{m}$. (C) DNA fragmentation assay in MDA-MB-231 cells as an index of apoptosis. Lane 1: showing control MDA-MB-231 cells; Lane 2, 3, and 4: cells treated with 15,18 , and $20 \mathrm{mg} / \mathrm{mL}$ of ADPE, respectively. (D) Flow cytometry analysis of MDA-MB231 cells after $48 \mathrm{~h}$ of treatment using annexin V/FITC \& PI double stain. Representative figures showing the population of viable (annexin V- PI-), early apoptotic (annexin V+ PI-), late apoptotic (annexin V+ PI+) and necrotic (annexin $\mathrm{V}$ - $\mathrm{PI}+$ ) cells.
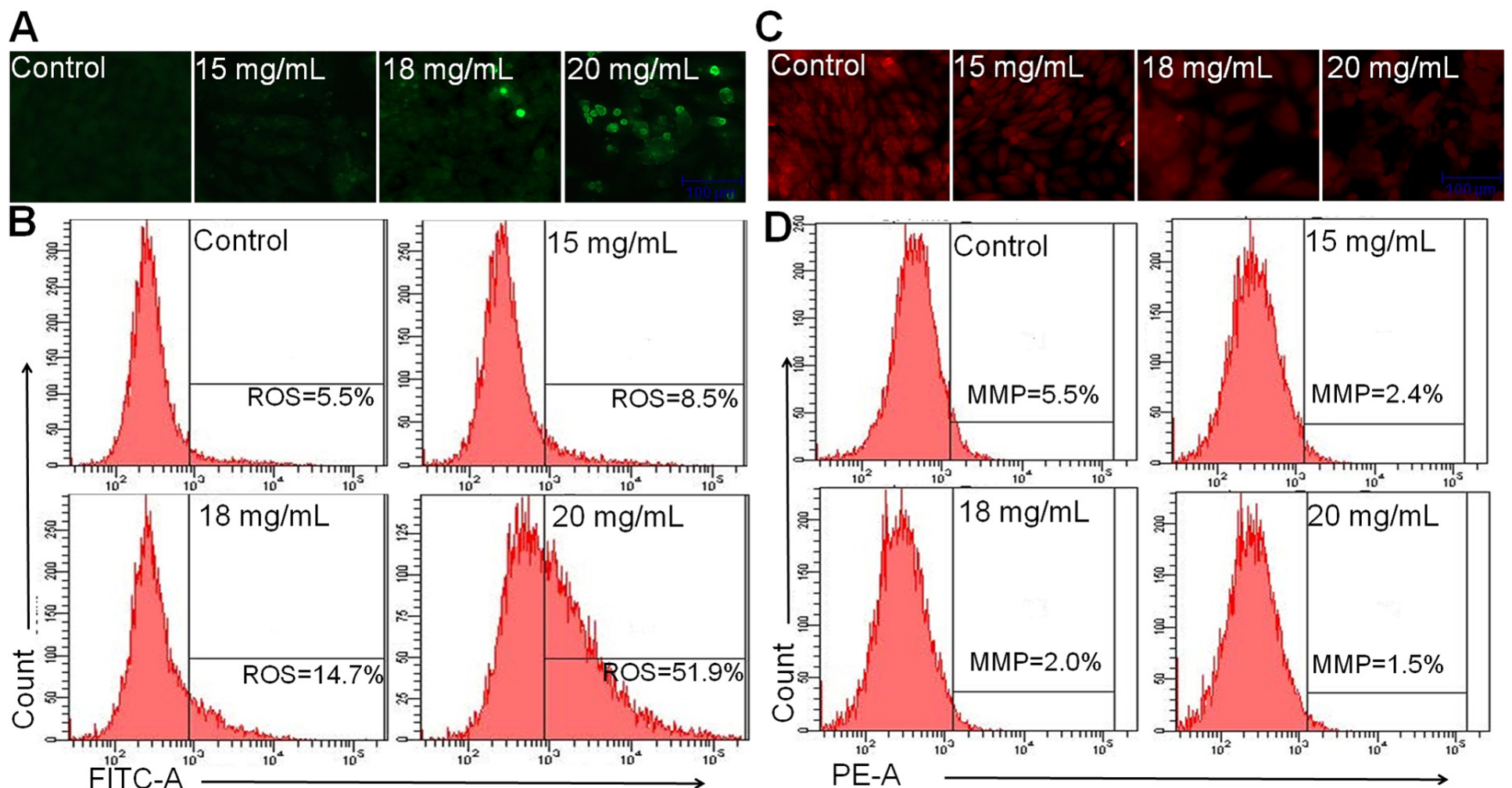

FITC-A

PE-A

\section{Figure 4}

Intracellular ROS generation and mitochondrial membrane potential of human MDA-MB-231 cells (A) Photomicrographs showing intracellular ROS generation induced by three effective concentrations $(15,18$ and $20 \mathrm{mg} / \mathrm{mL}$ ) of ADPE after $12 \mathrm{~h}$ incubation. Photomicrographs were taken with a fluorescence microscope. Scale bar $=100 \mu \mathrm{m}$ (B) The fluorescence in the cells is represented as the percentage of ROS production analyzed using flow cytometry. (C) Photographs indicate a decrease in MMP, an early event in apoptosis with increased concentrations of ADPE. Photomicrographs were taken with a fluorescence microscope. Scale bar=100 $\mu \mathrm{m}$ (D) Fluorescence in the cells is represented as the percentage of MMP reduction in MDA-MB-231 cells analyzed by flow cytometry. 

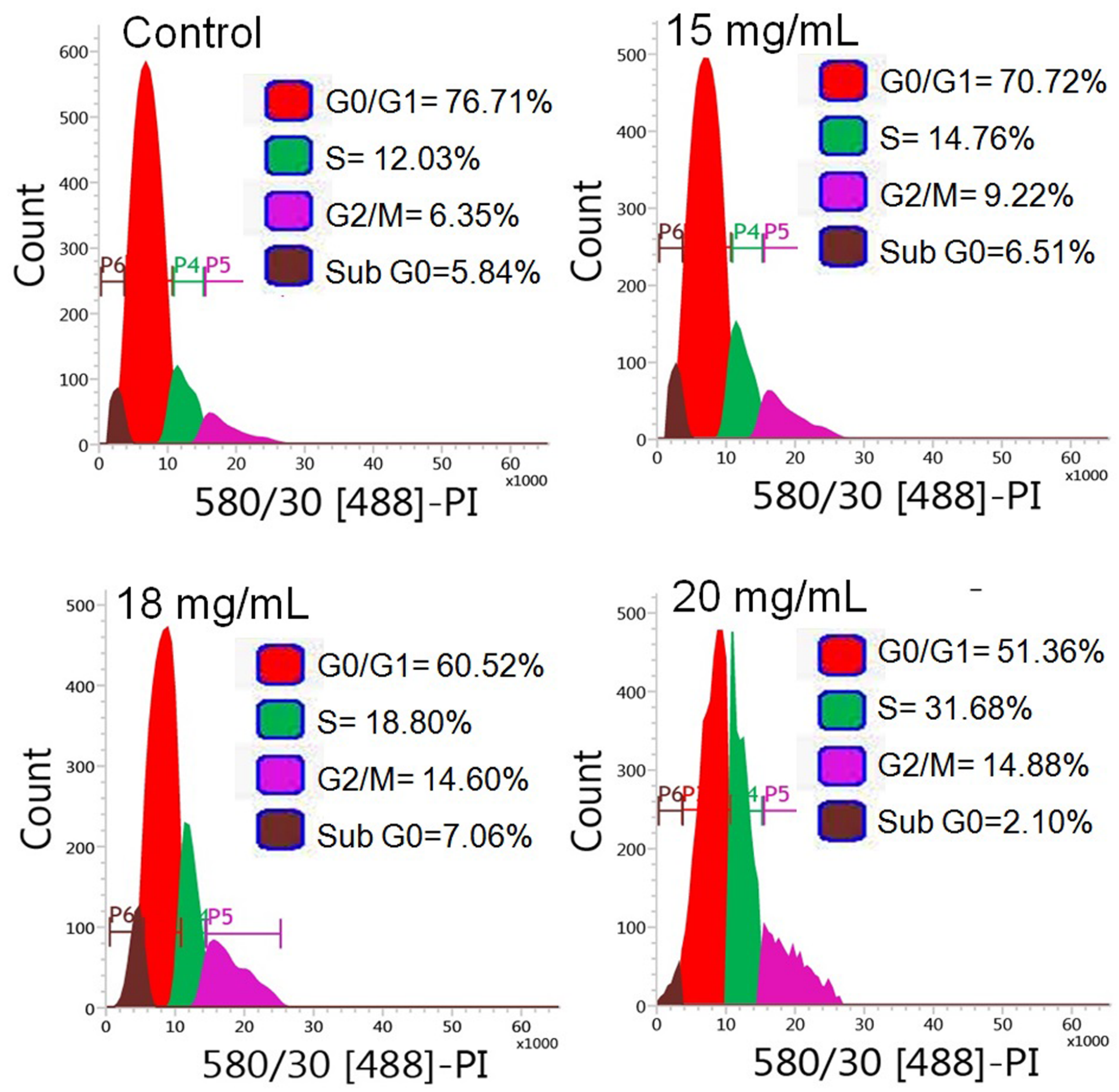

Figure 5

DNA content analysis by flow cytometry. Pictorial graph showing the mean proportion of cells in different phases of cell cycle treated with 15,18 and $20 \mathrm{mg} / \mathrm{mL}$ of ADPE at $48 \mathrm{~h}$. 


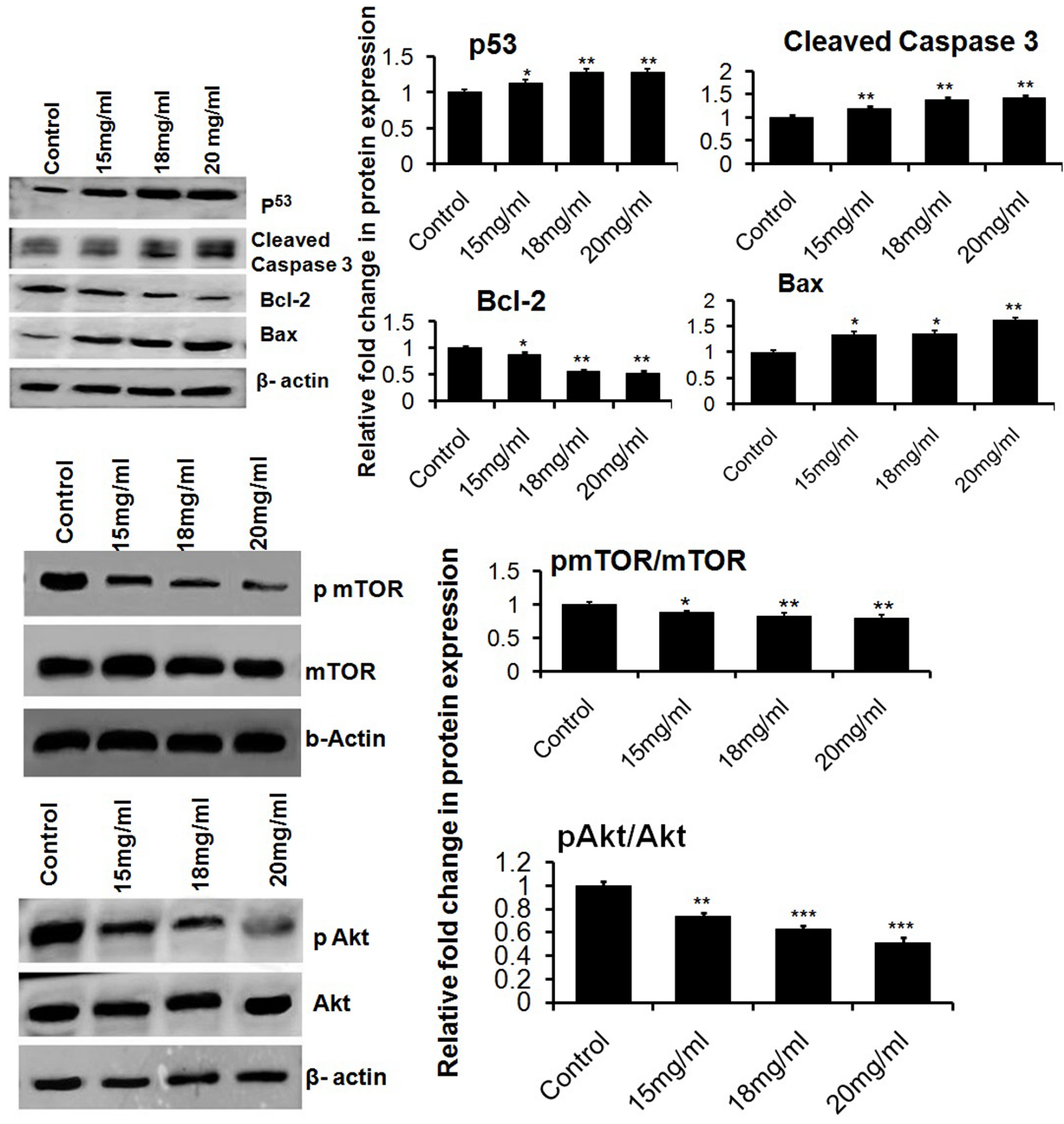

Figure 6

Immunoblot analysis shows the expression levels of p53, Bax, Bcl2, cleaved Caspase-3, pmTOR/mTOR and PAKT/AKT. The MDA-MB-231 cells were treated with effective concentrations of ADPE $(15,18$ and 20 $\mathrm{mg} / \mathrm{mL}$ ) for $48 \mathrm{~h}$. Equal amounts of total proteins (40 $\mu \mathrm{g} / \mathrm{lane}$ ) were subjected to 10-12 \% SDS-PAGE. Expression of p53, Bax, Bcl2, cleaved Caspase-3, pmTOR/mTOR, pAKT/AKT and $\beta$-actin were detected by 
western blotting using specific antibodies. Lane 1: $0 \mathrm{mg} / \mathrm{mL}$ (Control); lane 2: $15 \mathrm{mg} / \mathrm{mL}$; lane 3: 18 $\mathrm{mg} / \mathrm{mL}$; lane 4: $20 \mathrm{mg} / \mathrm{mL}$ of ADPE. The data represents mean $\pm S E M$ of three independent experiments.

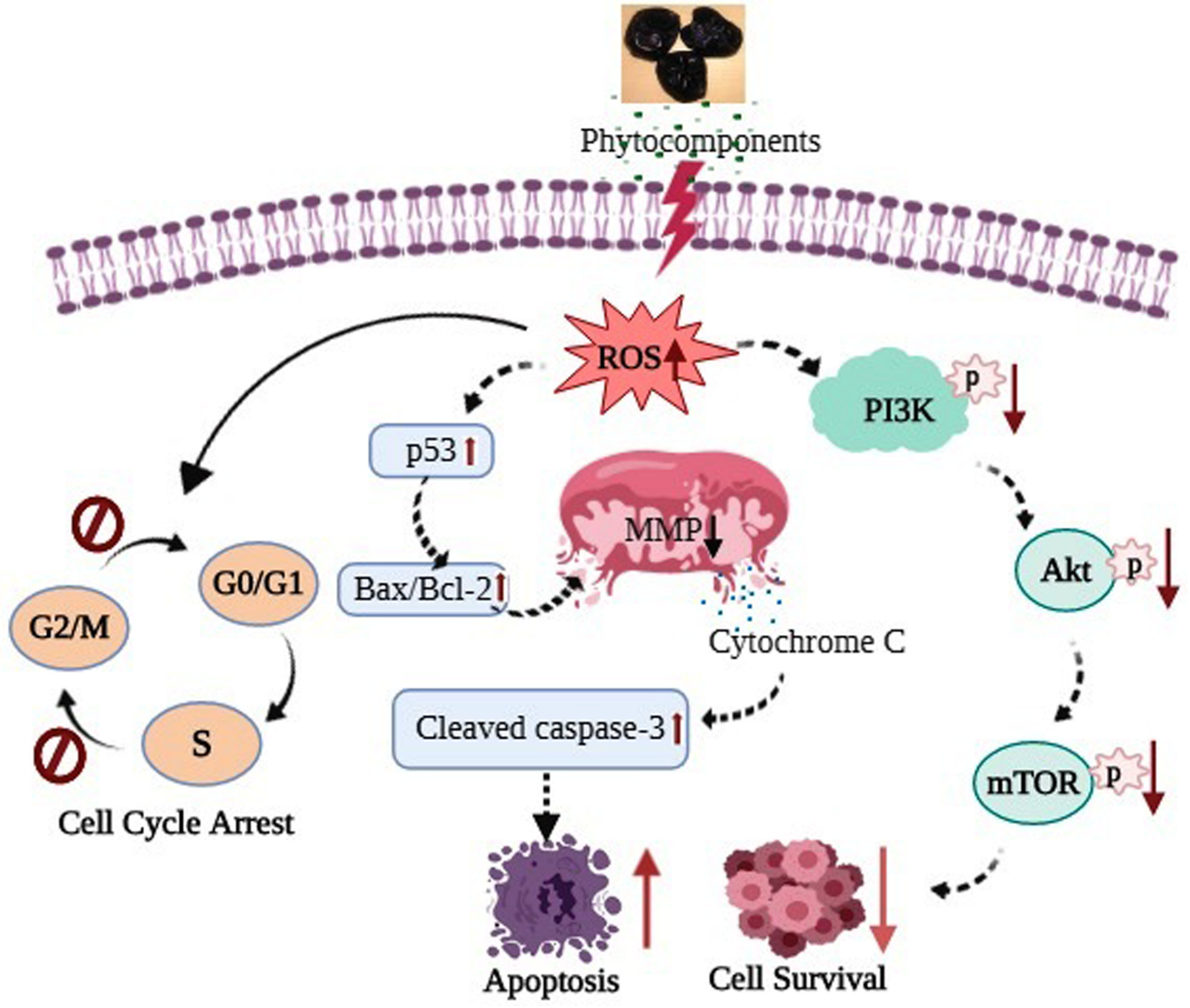

Figure 7

Schematic diagram summarizing the mechanism of ADPE action on MDA-MB-231 cells. Bioactive components from ADPE arrest G2/M and S phase checkpoints and induce apoptosis by upregulation of p53, Bax and cleaved caspase-3 thereby leading to downregulation of bcl-2 protein and Akt/mTOR pathway.

\section{Supplementary Files}

This is a list of supplementary files associated with this preprint. Click to download. 
- Table1.docx

Page 23/23 